\title{
Stable isotopes reveal dietary divergence between dispersal phenotypes in Tetrix subulata pygmy grasshoppers (Orthoptera: Tetrigidae)
}

\author{
EINAT KARPESTAM and ANDERS FORSMAN* \\ Ecology and Evolution in Microbial Model Systems, EEMiS, School of Natural Sciences, Linnaeus University, 39182 Kalmar, \\ Sweden; e-mails: einat.karpestam@Inu.se; anders.forsman@lnu.se
}

Key words. Orthoptera, dietary divergence, dispersal capacity, niche partitioning, pygmy grasshopper, stable isotopes, Tetrix subulata, wing dimorphism

\begin{abstract}
In some species of insects, individuals with fully developed wings and capable of flying coexist with flightless individuals that lack functional wings. Their diets may differ if long-winged individuals are more mobile and therefore likely to be better at finding and utilizing high quality food resources, or if they have different food preferences or physiological requirements. Despite its potential importance, differences in the diet of dispersal phenotypes have not been unequivocally demonstrated under natural conditions. To test for dietary divergence, we compared natural abundances of carbon and nitrogen stable isotope ratios $\left(\delta^{13} \mathrm{C}\right.$ and $\left.\delta^{15} \mathrm{~N}\right)$ in long- and short-winged free ranging Tetrix subulata pygmy grasshoppers collected as adults from two natural populations. Overall, this comparison of stable isotopes indicated long-term differences in the diet of the two wing morphs in both populations, but not between males and females of the same morph. We conclude that it is likely that the dietary niches of the long winged and flightless individuals differ under natural conditions. This may reduce intra-specific competition, offset the expected trade-off between flight capacity and reproduction and promote ecological speciation.
\end{abstract}

\section{INTRODUCTION}

Differences in the diets of individuals of different sexes, age classes, life-history variants or morphology (e.g., individuals that differ in the structure of their mouth parts) is well established for vertebrates (Smith \& Skulason, 1996; Bolnick et al., 2003). In generalist herbivorous insects, individuals often consume different part of the resources depending on availability, predator avoidance behaviour and specific physiological adjustments induced by food consumed during early development (e.g., Futuyma \& Peterson, 1985; Howard, 1993). In addition, individuals may vary in diet because they differ in dispersal capacity, ability to exploit patchy resources and in the rate at which they encounter different types of food.

In some species of insects, a flight capable morph with fully developed functional wings (macropterous or alate) coexists with individuals that lack wings (apterous) or have poorly developed wings (brachypterous) (Rehn \& Grant, 1955; Harrison, 1980; Zera \& Denno, 1997). Sometimes there is also a morph with wings of intermediate length, which is unable to fly (mesopterous) (Pushkar, 2009). Flight not only enables individuals to disperse and colonize new habitats it also facilitates smaller scale movements between habitat patches within heterogeneous environments (Roff \& Fairbairn, 1991; Müller et al., 2001). For example, early work by Denno et al. (1980) on the plant hopper, Porkelisia marginata, indicate that macropterous individuals are better at colonizing and utilizing high quality patches of vegetation. More recently, Pushkar (2009) reports that the macropterous form of the pygmy grasshopper Tetrix tuerki is found along the shorelines and on small isolated islands of alluvium in a river, while the brachypterous and mesopterous forms are only found along the shorelines of the river.

There are at least two reasons why one might expect a dietary niche divergence between long-winged flight capable individuals and short winged flightless individuals from the same population. As a consequence of their greater mobility, long-winged individuals may encounter a greater diversity and more highly preferred foods because they can search larger areas (e.g., Denno et al., 1980; Zera \& Denno, 1997). Flight-capable individuals may therefore be better able to find and utilize preferred food, while the diet of flightless individuals may be constrained by and restricted to what is locally available. In addition, flight-capable individuals may have different food requirements because of physiological demands associated with the development and maintenance of wings and flight muscles (Lock et al., 2006). To the best of our knowledge, no previous study has tested for dietary divergence in free-ranging individuals of different dispersal phenotypes in a wing polymorphic species.

A difference in foraging capacity and diet of the different dispersal phenotypes in wing polymorphic species might have important and interesting implications. For instance, it may contribute to and indicate reduced intraspecific competition for food and result in faster growth and a higher population density (Bolnick et al., 2003). Over a long time scale, if the food preferred by different

* E.K. and A.F. contributed equally to the design of this study, field work, collection and analyses of data, and to the writing of this paper. 
phenotypes is not available in the same habitat patches, dietary divergence may result in spatial sorting and ecological separation that may facilitate speciation (Schluter, 2009). In addition, a greater foraging ability may counteract the physiological, energetic and reproductive costs that are hypothesized to be associated with the development and possession of functional wings and ability to fly. That being able to fly may come at a cost of an impaired reproductive capacity is supported by the observation that females of some species autolyze their flight muscles (histolysis) before or during reproduction, that brachypterous females produce more or bigger eggs than macropterous females and that flightless females commence reproduction at an earlier age than those capable of flying (Harrison, 1980; Roff, 1986; Roff \& Fairbairn, 1991; Zera \& Denno, 1997; Simmons \& Thomas, 2004). However, the results of a recent meta-analysis by Guerra (2011) show that the trade-off between flight ability and reproduction is sometimes weak, maybe over- or underestimated when measured under artificial conditions in a laboratory and not manifested by all the species studied (e.g., Aukema, 1991).

In this study, we test for long-term differences in the diet of free-ranging long-winged and short-winged individuals of the pygmy grasshopper Tetrix subulata (Orthoptera: Tetrigidae) by comparing natural abundances of stable isotope ratios of carbon and nitrogen (Hood-Nowotny \& Knols, 2007). Howard (1993) demonstrated, using food preference experiments in the laboratory, that individuals of the polyphagous grasshopper Taenipoda eques show a strong fidelity to a single food source within a given meal but switch to complementary food sources between meals and days, and argues that dietary divergence should therefore be investigated over long time scales. Furthermore, laboratory feeding experiments may be used to investigate if individuals prefer different foods, but do not reveal whether the preferences translate into differences in the diets of free ranging individuals in the wild. Natural abundance of stable isotopes, especially those of carbon and nitrogen, are increasingly and extensively used to infer the diets of consumers and relations between species in ecosystems, since there are strong correlations between the chemistry of consumers and their diets (e.g., McCutchan et al., 2003; Vanderklift \& Ponsard, 2003; Girard et al., 2011). In contrast to laboratory feeding experiments, isotopic signatures provide a means of analyzing long-standing (depending on the rate of tissue turnover) differences in the diets of free ranging animals in their natural environment, which reflect the combined effects of preferences, constraints, competing demands, and variation in foraging ability and encounter rates with specific foods (Deniro \& Epstein, 1978a, b; Bolnick et al., 2002; Bearhop et al., 2004; Hood-Nowotny \& Knols, 2007; Karpestam \& Forsman, 2011). To assess the generality of our results we replicate this study by sampling and comparing stable isotope ratios in free ranging long- and short-winged individuals in two natural populations.

\section{MATERIAL AND METHODS}

\section{Study species}

The pygmy grasshopper T. subulata is a small $(<15 \mathrm{~mm}$ total body length, mean dry body mass of $0.07 \mathrm{~g}$ ), diurnal, ground dwelling and widely distributed insect that inhabits biomes ranging from tropical rainforests to the arctic regions in Europe, Asia and north to southern north America (Mexico), but not in the south-eastern United States (Rehn \& Grant, 1955; Holst, 1986). They usually inhabit damp places, where they live on the surface of the soil and feed on microalgae growing on moist soils, mosses, humus or detritus (Holst, 1986; Karpestam \& Forsman, 2011). Like many species of Tetrigidae, the lengths of the pronotum and wings of $T$. subulata are very variable. The relative frequencies of macropterous and brachypterous animals differ among populations (Rehn \& Grant, 1955). Previous analyses based on data for $>2,500$ wild caught individuals from 12 populations in the southeast of Sweden indicate that the incidence of the long-winged (macropterous) morph is higher and changes faster between years in disturbed habitats in early stages of succession than in stable habitats (Berggren et al., 2012). Common garden and mother-offspring resemblance studies further indicate that variation among populations and families is genetically determined and that the long-winged phenotype is not induced by developmental plasticity in response to maternal condition, rearing density or individual growth rate. Finally, performance trials show that only the macropterous morph is capable of flight and their propensity to fly depends on the environment as they are less likely to fly in benign than harsh environments (Berggren et al., 2012).

\section{Source populations, sampling and general procedure}

To determine whether long- and short-winged individuals differ in their diet, we analyzed and compared the stable carbon and nitrogen isotope signatures of the hind femur of adult individuals collected from two natural populations. We collected 92 (long-winged $n=28$, short-winged $n=64$ ) females from a natural population in an alkaline fen (Vanserum) on Öland (island in south east Sweden) in May 2010. In addition, we used legs from 104 adult individuals (long-winged $n=25$ females and 15 males; short-winged $n=44$ females and 20 males) that were collected along the shoreline of a small pond at the edge of a clear-cut (Påryd) pine forest on the mainland in south-east Sweden in June 2011. These grasshoppers were released immediately after removal of one hind femur.

Samples (i.e., legs) were oven dried at $60^{\circ} \mathrm{C}$ for $48 \mathrm{~h}$, ground to a fine powder and weighed (approximately $1-2 \mathrm{mg}$ ) into tin capsules and sent to UC Davis Stable Isotope Facility (University of California, Davis, CA) for carbon and nitrogen stable isotope analysis using an ANCA-GSL and PDZ Europa 20-20 isotope ratio mass spectrometer (Secron Ltd., Cheshire, UK). Results were expressed as $\delta^{15} \mathrm{~N}$ and $\delta^{13} \mathrm{C}$, defined as the \%o deviation of the sample from international reference (i.e. Pee Dee belemnite carbonate for $\delta^{13} \mathrm{C}$ or air for $\delta^{15} \mathrm{~N}$ ) using the equation:

$$
\delta \mathrm{X}=\left[\left(\mathrm{R}_{\text {sample }} / \mathrm{R}_{\text {reference }}\right)-1\right] * 1000,
$$

where $\mathrm{X}={ }^{15} \mathrm{~N}$ or ${ }^{13} \mathrm{C}$ and $\mathrm{R}_{\text {sample }}$ or $\mathrm{R}_{\text {reference }}$ is the corresponding isotopic ratio ${ }^{15} \mathrm{~N} /{ }^{14} \mathrm{~N}$ or ${ }^{13} \mathrm{C} /{ }^{12} \mathrm{C}$ of the sample and the reference, respectively (Hood-Nowotny \& Knols, 2007). The long term precision of this analysis (standard deviate of the internal standard) was $\pm 0.2 \%$ for $\delta^{13} \mathrm{C}$ and $\pm 0.3 \%$ for $\delta^{15} \mathrm{~N}$.

\section{Statistical analyses}

To test whether the wing morphs differed in their diets we performed separate analyzes of data for $\delta^{13} \mathrm{C}$ and $\delta^{15} \mathrm{~N}$. For the population at Vanserum, we had data for females only, and used 
A

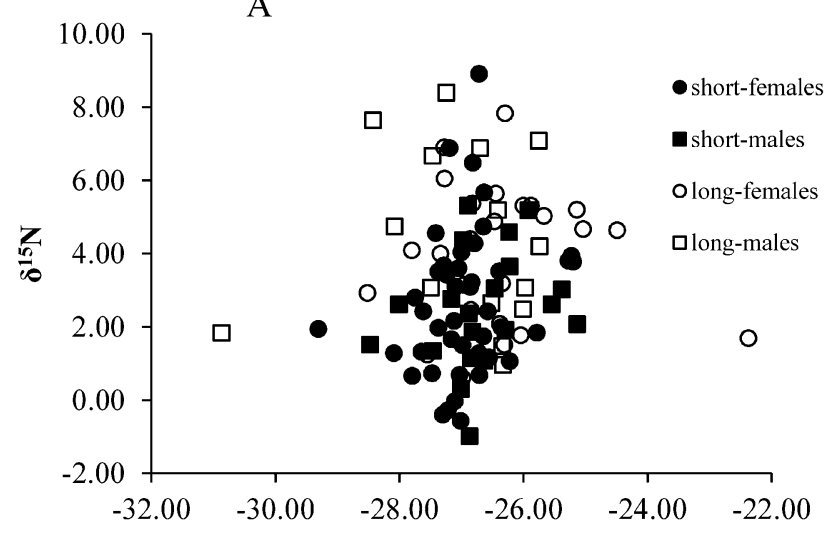

B

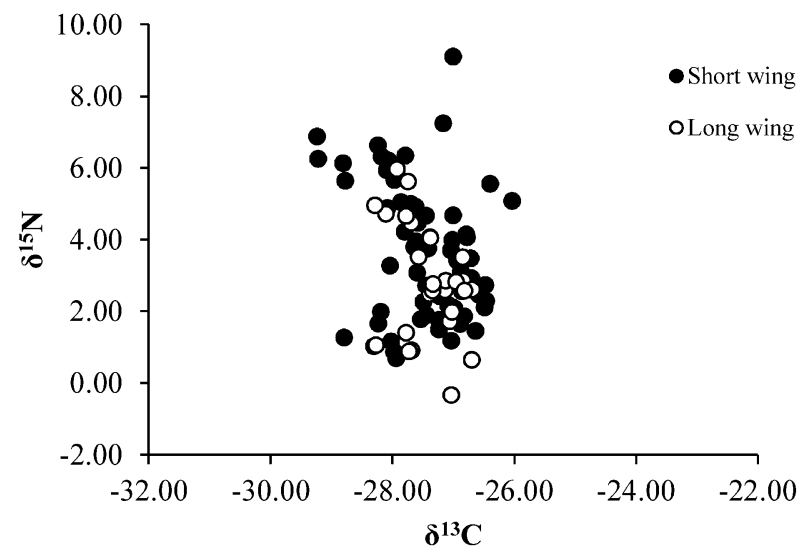

Fig 1. Biplot of the $\delta^{13} \mathrm{C}$ and $\delta^{15} \mathrm{~N}$ isotope signatures of short winged (filled symbols) and long winged (open symbols) Tetrix subulata from two different natural populations. A - females and males from Påryd. Data for the 3 outliers that were omitted from the statistical analyses (see text) are included in this figure. $\mathrm{B}$ - females from Vanserum.

a two-sample $t$-test for each isotope. For the population at Påryd, we had data for both males and females and performed a two-factor ANOVA with sex, wing morph and their interaction as explanatory factors. Because the sex by wing morph interaction was significant (for carbon) we continued with separate $t$-tests for each sex and isotope. Bartlett's test revealed that the variance of both the carbon and nitrogen data for individuals from Vanserum and that for nitrogen for those from Påryd was
TABLE 2. Results of the ANOVAs of the effects of wing morph and sex on $\delta^{13} \mathrm{C}$ and $\delta^{15} \mathrm{~N}$ stable isotopes in wild caught Tetrix subulata. Data for 104 individuals collected as adults from a natural population at Påryd.

\begin{tabular}{cccccc}
\hline Isotope & Source of variation & MS & $F$ & $d f$ & $P$ \\
\hline \multirow{2}{*}{$\delta^{13} \mathrm{C}$} & Wing morph & 0.76 & 1.29 & 1,96 & 0.26 \\
& Sex & 0.035 & 0.06 & 1,96 & 0.81 \\
& Wing morph*Sex & 0.91 & 1.54 & 1,96 & 0.21 \\
\hline \multirow{2}{*}{$\delta^{15} \mathrm{~N}$} & Wing morph & 60.31 & 15.58 & 1,100 & $\mathbf{0 . 0 0 0 1}$ \\
& Sex & 0.879 & 0.23 & 1,100 & 0.634 \\
& Wing morph*Sex & 1.743 & 0.45 & 1,100 & 0.503 \\
\hline
\end{tabular}

homogenous and were all normally distributed. The nonnormality of carbon data for the individuals from Påryd resulted from one outlier in each of 3 out of 4 groups. These 3 outliers were excluded from the statistical analyses in the results reported below. If the 3 outliers from Paryd were included, the results indicate a difference in $\delta^{13} \mathrm{C}$ in individuals of the shortwinged and long-winged morphs that depended on sex (as evidenced by a statistically significant effect of the interaction between sex and wing morph, $F_{1,99}=4.91, P=0.02$ ).

\section{RESULTS}

Overall, the analyses of stable isotopes indicate differences in the past diet of the different wing morphs but not of the sexes of a particular morph. Mean natural abundances of $\delta^{13} \mathrm{C}$ and $\delta^{15} \mathrm{~N}$ in individuals originating from different populations and belonging to different wing morphs and different sexes are shown in Table 1. Bi-plots portraying individual data points in each population are shown in Fig 1.

Among females from Vanserum, short-winged individuals had higher $\delta^{15} \mathrm{~N}$ values than long-winged individuals (Table 1, Fig. 1), but $\delta^{13} \mathrm{C}$ did not differ between wing morphs.

In the Påryd population, short-winged individuals had lower $\delta^{15} \mathrm{~N}$ values than long-winged individuals, this difference between wing morphs was evident in both sexes, and there was no difference between males and females of a particular morph (Tables 1 and 2). In the case of $\delta^{13} \mathrm{C}$, there was no significant difference between the two wing morphs or sexes, nor was the interaction significant (Table 2).

TABle 1. Comparison of natural abundance of $\delta^{13} \mathrm{C}$ and $\delta^{15} \mathrm{~N}$ stable isotopes in short winged and long winged male and female Tetrix subulata collected from natural populations at Påryd and Vanserum, respectively. $t$ and $P$ indicate results from separate twosample $t$-tests for differences between wing morphs.

\begin{tabular}{|c|c|c|c|c|c|c|c|c|c|c|c|c|}
\hline \multirow{3}{*}{$\begin{array}{l}\text { Population } \\
\text { Sex }\end{array}$} & \multicolumn{6}{|c|}{$\delta^{13} \mathrm{C} \%$} & \multicolumn{6}{|c|}{$\delta^{15} \mathrm{~N} \%$} \\
\hline & \multicolumn{2}{|c|}{ Short winged } & \multicolumn{2}{|c|}{ Long winged } & & \multirow{2}{*}{$P$} & \multicolumn{2}{|c|}{ Short winged } & \multicolumn{2}{|c|}{ Long winged } & \multirow{2}{*}{$t$} & \multirow{2}{*}{$P$} \\
\hline & $n$ & Mean (SD) & $n$ & Mean (SD) & & & $n$ & Mean (SD) & $n$ & Mean (SD) & & \\
\hline \multicolumn{13}{|l|}{ Påryd } \\
\hline Females & 42 & $-26.86(0.61)$ & 24 & $-26.53(0.91)$ & -1.866 & 0.066 & 44 & $2.62(1.99)$ & 25 & $4.00(1.87)$ & -2.86 & 0.006 \\
\hline Males & 20 & $-26.66(0.82)$ & 14 & $-26.75(0.85)$ & 0.30 & 0.76 & 20 & $2.49(1.61)$ & 15 & $4.42(2.35)$ & -2.67 & 0.013 \\
\hline \multicolumn{13}{|l|}{ Vanserum } \\
\hline Females & 64 & $-27.42(0.70)$ & 28 & $-27.43(0.49)$ & 0.03 & 0.972 & 64 & $3.58(1.88)$ & 28 & $2.82(1.59)$ & 1.99 & 0.050 \\
\hline
\end{tabular}




\section{DISCUSSION}

Diet of individuals is likely to be the result of a complicated interplay between food preferences, physiological demands, food availability, competition and the competing demands such as predator avoidance and temperature regulation (Arnold, 1977; Bolnick et al., 2003; Karpestam \& Forsman, 2011). In this study we aimed to test for an effect of dispersal capacity on long-term dietary divergence by analyzing and comparing stable carbon and nitrogen isotopes Tetrix subulata pygmy grasshopper individuals that belonged to either a long-winged flight capable or a short-winged flightless phenotype. We found significant differences in the abundance of $\delta^{15} \mathrm{~N}$ isotopes in long- and short-winged individuals of both sexes and both populations, but not in $\delta^{13} \mathrm{C}$ isotopes (Table 1, Fig. 1).

Since our data is based on tissue samples from freeranging individuals collected as adults from natural populations these differences are indicative of a long-standing difference in the realized diet of the two wing morphs. This dietary divergence may be a consequence of the greater mobility of the long-winged morph, which enables it to utilize preferred high quality foods even if they are scarce and scattered in space (Denno et al., 1980). In addition, long and short-winged individuals may utilize different foods even within the same area because they have different innate preferences and physiological demands. In T. subulata the flight muscles of the long-wing morph are fully developed whereas short-winged individuals lack flight muscles (Berggren et al., 2012). It has been shown for another $T$. subulata population that the long-winged morph contains higher levels of protein than the short-winged morph, probably because of the wing muscles (Lock et al., 2006). However, as only a leg was used to estimate isotope levels in our study the presence or absence of flight muscles per se cannot account for the difference recorded between wing morphs in our study. It is not clear from the study of Locke et al. (2006) whether the difference in nitrogen content reflected difference in diet or differential digestion or allocation of the ingested food. Mole \& Zera (1993) compared short and longed-wing morphs of the cricket Gryllus rubens that were fed the same diet, and found that consumption and digestion of food did not differ in the two morphs, but short-winged individuals invest more in their ovarian mass. It is therefore possible, that isotope signatures of legs of long- and short-winged individuals of $T$. subulata differ in part because of the way they each allocate resources and nutrients to growing legs versus developing the flight apparatus. Finally, it is possible that the different wing morphs feed on the same plant species but by utilizing post-ingestive mechanisms are able to regulate their nutrient intake (Behmer, 2009).

Dispersal polymorphism in insects may reflect a genetic polymorphism controlled by either two alleles at a single locus or by additive and interactive effects of several loci (Aukema, 1995; Roff, 1996; Roff \& Fairbairn, 2001; Caillaud et al., 2002; Roff \& Fairbairn, 2007). The expression and suppression of the development of long functional wings may also result from developmental plasticity in response to maternal quality and condition, local population density, temperature, photoperiod and/or the quality and quantity of food (Harrison, 1980; Aukema, 1995; Zera \& Denno, 1997; Müller et al., 2001; Simmons \& Thomas, 2004; Braendle et al., 2006; Poniatowski \& Fartmann, 2009). If the wing morph of an individual depends on the food consumed during growth, it is difficult to infer dietary divergence between long- and short-winged individuals based on comparisons of isotope signatures of wild-caught adults. However, common garden and mother-offspring resemblance studies indicate that differences in wing morph frequencies among populations and families is genetically determined, and that the long-winged phenotype in T. subulata is not induced by developmental plasticity in response to maternal condition, rearing density or individual growth rate. For instance, there is a very strong correlation across populations between the incidence of the long-winged phenotype in samples of wild caught individuals and samples of individuals reared in captivity under standardized conditions and identical food regimes (Berggren et al., 2012). Moreover, the rate of tissue turnover in the muscles in the femurs of grasshoppers is high. For instance, Judd et al. (2011) demonstrated, based on a feeding experiment and analysis of stable isotopes, that in the lubber grasshopper, Romalea microptera, femur muscles are built primarily of nitrogen and carbon ingested during the period from adult moult to first oviposition. Taken together this enables us to discriminate cause and effect with some certainty, and we propose that long-winged flight capable individuals of T. subulata do not develop long wings because they eat different things before emergence as an adult. Instead, it seems more likely that the diet of long-winged individuals is different from that of shorter-winged individuals because they are more mobile and better able to utilize scattered food resources in spatially heterogeneous environments.

In this study, we were unable to identify the food actually consumed by the different morphs, since the base values of the potential food items in the two environments studied are not known to us. Thus any inference about the nature of the difference between the two populations would be speculative. However, the two populations studied inhabited very different environments, at Vanserum it was a stable meadow in an alkaline fen, while at Påryd it was a clear-cut area in coniferous forest. It is therefore likely that the species composition of available potential foods differed in the two environments, and it is also possible that the isotope signatures of the same plant species differed between environments depending on the local properties of the soil (see discussion in Karpestam \& Forsman, 2011).

The combination of dispersal polymorphism with dietary divergence indicated by our results in both environments may have interesting ecological and evolutionary consequences for the populations and species. For instance, it may decrease the intensity of intra-specific competition and thereby influence the density and 
dynamics of populations (Bolnick et al., 2003). If the preferred food is available in different habitat patches, this may result in spatial separation between morphs, contribute to evolutionary divergence and ultimately promote ecological speciation (Schluter, 2009). Less speculatively, our findings have implications for the trade-off between flight capacity and reproduction. Studies of wing polymorphism in other species of insects suggest that wings and flight musculature are energetically costly to develop and maintain, which impairs their reproductive capacity and has an important affect on the spatiotemporal dynamics of the polymorphism (Harrison, 1980; Zera, 1984; Roff, 1986, 1990; Roff \& Fairbairn, 1991; Zera \& Denno, 1997; Simmons \& Thomas, 2004; Braendle et al., 2006). However, the evidence for the hypothesized trade-off is mixed (see recent review by Guerra, 2011) and in some species the pattern is opposite to that expected. For instance, in the carabid beetles Calathus cinctus and C. melanocephalus, long-winged females produce more eggs than short-winged females, and also tended to produce the eggs over a longer period (Aukema, 1991). Results of a previous study on several populations of $T$. subulata carried out over years, show that long winged females do not consistently produce smaller or fewer clutches and do not have longer inter-clutch intervals than shorter winged females (Berggren et al., 2012). In this respect, our present finding that the diets of longand short-winged individuals differ, may account for why the hypothesized trade-off between flight capacity and reproduction does not occur in T. subulata.

ACKNOWLEDGEMENTS. We are grateful to L. Wennersten, P. Tibblin and J. Tinnert for help in the field. The study was supported by The Swedish Research Council and Linnaeus University.

\section{REFERENCES}

ARNold S.J. 1977: Polymorphism and geographic variation in the feeding behavior of the garter snake Thamnophis elegans. - Science 197: 676-678.

Aukema B. 1991: Fecundity in relation to wing-morph of three closely related species of the melanocephalus; group of the genus Calathus (Coleoptera: Carabidae). - Oecologia 87: 118-126.

AUKEMA B. 1995: The evolutionary significance of wing dimorphism in carabid beetles (Coleoptera: Carabidae). - Res. Popul. Ecol. 37: 105-110.

Bearhop S., Adams C.E., Waldron S., Fuller R.A. \& Macleod H. 2004: Determining trophic niche width: a novel approach using stable isotope analysis. - J. Anim. Ecol. 73: $1007-1012$.

Behmer S.T. 2009: Insect herbivore nutrient regulation. Annu. Rev. Entomol. 54: 165-187.

Berggren H., Tinnert J. \& Forsman A. 2012: Spatial sorting may explain evolutionary dynamics of wing polymorphism in pygmy grasshoppers. - J. Evol. Biol. 25: 2126-2138.

Bolnick D.I., YANG L.H., Fordyce J.A., Davies J.M. \& SvanBÄCK R. 2002: Measuring individual-level resource specialization. - Ecology 83: 2936-2941.

Bolnick D.I., Svanbäck R., Fordyce J.A., Yang L.H., Davis J.M., Hulsey C.D. \& Forister M.L. 2003: The ecology of individuals: incidence and implications of individual specialization. - Am. Nat. 161: 1-28.

Braendle C., Davis G.K., Brisson J.A. \& Stern D.L. 2006: Wing dimorphism in aphids. - Heredity 97: 192-199.

Caillaud M.C., Boutin M., Braendle C. \& Simon J.C. 2002: A sex-linked locus controls wing polymorphism in males of the pea aphid, Acyrthosiphon pisum (Harris). - Heredity 89: 346-352.

Deniro M.J. \& Epstein S. 1978a: Carbon isotopic evidence for different feeding patterns in 2 hyrax species occupying same habitat. - Science 201: 906-908.

Deniro M.J. \& EpsteIn S. 1978b: Influence of diet on distribution of carbon isotopes in animals. - Geochim. Cosmochim. Acta 42: 495-506.

Denno R.F., Raupp M.J., Tallamy D.W. \& Reichelderfer C.F. 1980: Migration in heterogeneous environments - differences in habitat selection between the wing forms of the dimorphic planthopper, Prokelisia marginata (Homoptera, Delphacidae). -Ecology 61: 859-867.

Futuyma D.J. \& Peterson S.C. 1985: Genetic variation in the use of resources by insects. - Annu. Rev. Entomol. 30: 217-238.

Girard J., Baril A., Mineau P. \& Fahrig L. 2011: Carbon and nitrogen stable isotope ratios differ among invertebrates from field crops, forage crops, and non-cropped land uses. - Ecoscience 18: 98-109.

GUERRA P.A. 2011: Evaluating the life-history trade-off between dispersal capability and reproduction in wing dimorphic insects: a meta-analysis. - Biol. Rev. 86: 813-835.

HARRISON R.G. 1980: Dispersal polymorphism in insects. Annu. Rev. Ecol. Syst. 11: 95-118.

Holst K.T. 1986: The Saltatoria of Northern Europe. - Fauna Entomol. Scand. 16: 1-127.

Hood-Nowotny R. \& Knols B.G.J. 2007: Stable isotope methods in biological and ecological studies of arthropods. Entomol. Exp. Appl. 124: 3-16.

HOWARD J. 1993: Temporal pattern of resource use and variation in diets of individual grasshoppers (Orthoptera: Acrididae). J. Insect Behav. 6: 441-453.

Judd E.T., Wessels F.J., Drewry M.D., Grove M., Wright K., HahN D.A. \& HatLe J.D. 2011: Ovariectomy in grasshoppers increases somatic storage, but proportional allocation of ingested nutrients to somatic tissues in unchanged. - Aging Cell 10: 972-979.

Karpestam E. \& Forsman A. 2011: Dietary differences among colour morphs of pygmy grasshoppers revealed by behavioural experiments and stable isotopes. - Evol. Ecol. Res. 13: 461-477.

Lock K., Verslycke T. \& JANSSEN C.R. 2006: Energy allocation in brachypterous versus macropterous morphs of the pygmy grasshopper Tetrix subulata (Orthoptera: Tetrigidae). - Entomol. Gener. 28: 269-274.

McCutchan J.H., Lewis W.M., Kendall C. \& McGrath C.C. 2003: Variation in trophic shift for stable isotope ratios of carbon, nitrogen, and sulfur. - Oikos 102: 378-390.

Mole S. \& Zera A.J. 1993: Differential allocation of resources underlies the dispersal-reproduction trade-off in the wingdimorphic cricket, gryllus-rubens. - Oecologia 93: 121-127.

Müller C.B., Williams I.S. \& Hardie J. 2001: The role of nutrition, crowding and interspecific interactions in the development of winged aphids. - Ecol. Entomol. 26: 330-340.

Poniatowski D. \& Fartmann T. 2009: Experimental evidence for density-determined wing dimorphism in two bushcrickets (Ensifera: Tettigoniidae). - Eur. J. Entomol. 106: 599-605. 
PushKaR T.I. 2009: Tetrix tuerki (Orthoptera, Tetrigidae): Distribution in Ukraine, ecological characteristic and features of biology. - Vest. Zool. 43: 15-28.

ReHN J.A.G. \& GRANT H.J.J. 1955: Tetrix subulata (Orthoptera; Acridoidea; Tetrigidae) as occurring in North America. Proc. Acad. Nat. Sci. Phila. 107: 145-165.

RofF D.A. 1986: The evolution of wing dimorphism in insects. - Evolution 40: 1009-1020.

RofF D.A. 1990: The evolution of flightlessness in insects. Ecol. Monogr. 60: 389-421.

RofF D.A. 1996: The evolution of threshold traits in animals. Quart. Rev. Biol. 71: 3-35.

RofF D.A. \& FaIRbairn D.J. 1991: Wing dimorphism and the evolution of migratory polymorphisms among the Insecta. Am. Zool. 31: 243-251.

RofF D.A. \& Fairbairn D.J. 2001: The genetic basis of dispersal and migration, and its consequences for the evolution of correlated traits. In Clobert J., Danchin E., Dhondt A.A. \& Nichols J.D. (eds): Dispersal. Oxford University Press, New York, pp. 191-202.
Roff D.A. \& Fairbairn D.J. 2007: The evolution and genetics of migration in insects. - Bioscience 57: 155-164.

SCHLUTER D. 2009: Evidence for ecological speciation and its alternative. - Science 323: 737-741.

Simmons A.D. \& Thomas C.D. 2004: Changes in dispersal during species' range expansions. - Am. Nat. 164: 378-395.

SMith T.B. \& SkULASON S. 1996: Evolutionary significance of resource polymorphisms in fishes, amphibians, and birds. Annu. Rev. Ecol. Syst. 27: 111-133.

VANDERKLIFT M.A. \& PonSARD S. 2003: Sources of variation in consumer-diet delta(15)N enrichment: a meta-analysis. Oecologia 136: 169-182.

ZeRA A.J. 1984: Differences in survivorship, development rate and fertility between the longwinged and wingless morphs of the waterstrider, Limnoporus canaliculatus. - Evolution 38: $1023-1032$.

Zera A.J. \& DenNo R.F. 1997: Physiology and ecology of dispersal polymorphism in insects. - Annu. Rev. Entomol. 42: 207-230.

Received June 7, 2012; revised and accepted August 13, 2012 